\title{
Literatura e memória: configuração estética da obra De mim já nem se lembra, de Luiz Ruffato
}

\author{
Literature and memory: aesthetic configuration of the work \\ De mim já nem se lembra, by Luiz Ruffato
}

\author{
Daniele Cristina da Silva ${ }^{1}$ \\ Walnice Aparecida Matos Vilalva² \\ ${ }^{1}$ Instituto Federal de Educação, Ciência e Tecnologia do Mato Grosso (IFMT). \\ Programa de Pós-Graduação em Estudos Literários (PPGEL) da Universidade do Estado de Mato Grosso (UNEMAT). \\ Tangará da Serra, Mato Grosso, Brasil. \\ 2Departamento de Letras e Programa de Pós-Graduação em Estudos Literários (PPGEL) \\ da Universidade do Estado de Mato Grosso (UNEMAT). Tangará da Serra, Mato Grosso, Brasil
}

Resumo: De mim já nem se lembra (2016), de Luiz Ruffato, é um romance epistolar que apresenta assuntos caros ao seu autor, quais sejam, as memórias familiares. No presente artigo, situando-o em uma produção literária contemporânea, propor-se-á um diálogo sobre a multiplicidade de vozes que ressoam juntamente com os discursos dos narradores e que contribuem para a construção estética da obra. Na primeira parte do artigo, apresentar-se-á uma breve reflexão sobre a origem do gênero romanesco e seu desdobramento em romance epistolar para, então, discutir sobre a figura do narrador e sua configuração na obra em questão, sem a pretensão de esgotar as possibilidades de leituras sobre essa figura tão cara à narrativa. Posteriormente, aprofundar-se-á na análise do romance, evidenciando suas particularidades quanto à configuração das memórias familiares, tendo como principal recurso a concepção bakhtiniana do plurilinguíssimo no romance. Dessa forma, será evidenciado o modo como as categorias tempo e espaço são relativizadas no universo romanesco destacando, assim, a engenhosidade da obra.

Palavras-chave: literatura contemporânea; romance; memórias.

Abstract: De mim já nem se lembra (2016), by Luiz Ruffato, it is an epistolary novel that presentes invaluable subjects to its author, that are, the family memoirs. In the present article, situating it in a contemporary literary production, a dialogue will be proposed about the multiplicity of voices that resonate with the narrators' discourses and contribute to an aesthetic construction of the work. In the first part of the article, a brief reflection on the origin of the romanesque genre and its unfolding in epistolary romance will be presented to discuss the narrator figure and its configuration in the work in question, without the pretension of exhausting the possibilities of reading about this figure so important to the narrative. Later, it will deepen on the analysis of the novel evidencing its peculiarities as to the configuration of the familiar memories, having as main resource the Bakhtinian conception of the plurilingual in the novel. So, it will be evidenced how the time and space categories are relativized in the romanesque universe emphasizing the ingenuity of the work.

Keywords: contemporary literature; novel; memoirs. 


\section{Introdução}

A primeira edição da obra De mim já nem se lembra, de Luiz Ruffato, foi publicada em 2007 pela editora Moderna, visando, como público leitor, ao alunado de um programa de Educação de Jovens e Adultos - EJA. Em 2016, a segunda edição - a qual constitui o corpus de análise deste artigo - veio a público pela Companhia das Letras. Trata-se, pois, de um romance de cunho epistolar, o que pode soar, a princípio, anacrônico, por se tratar de literatura contemporânea. Muito difundido no século XIII, ainda hoje inúmeros autores enveredam-se por esse caminho para dar forma às suas narrativas ficcionais.

Em De mim já nem se lembra, apesar de ser notada a troca de correspondências entre mãe e filho, há somente cartas escritas pelo personagem Célio. Também dá forma ao romance dois textos que funcionam como espécie de introdução e conclusão - Introdução necessária e Apêndice -narrados em terceira pessoa, por Luiz, irmão de Célio. Este narrador, ao tornar-se o responsável por organizar e narrar as memórias do irmão mais velho contidas nas cartas, de onde emana um emaranhado de outras vozes, torna-se uma espécie de regente de um coro. Os conflitos pessoais e sociais que emanam desses documentos familiares funcionam como instrumentos de percussão dando às memórias o arranjo e a harmonia necessária para a composição do romance.

Ao todo, a obra comporta 50 cartas escritas por Célio tendo como destinatário a mãe, ou seja, a única e absoluta leitora. Apesar das cartas-respostas não comporem o romance, confirma-se a existência no universo ficcional pelo conteúdo contratado entre as sucessivas cartas escritas pelo filho.

O estudo literário de obras contemporâneas percorre um caminho sinuoso entre a perenidade e dissolubilidade de tais produções. Além do mais, é indispensável cautela para não sucumbir em uma leitura impressionista, já que a crítica sobre tais obras ainda estão por se constituir, quando não a própria obra, como é o caso das produções de Luiz Ruffato, em que a prática de alteração, reescrita e reorganização dos textos estão imbricadas no seu trabalho de escrita. Atividade que o autor faz de maneira consciente e proposital, como expôs, recentemente, em entrevista à Rádio Unesp:

[...] eu só vou parar de mexer nos meus livros no momento em que eu estiver morto. Aí não tem como (risos) não tem jeito mais. Mas até quando eu, assim puder, eu vou continuar mexendo justamente por isso, porque eu procuro a forma ideal de expressão (RUFFATO, 2018). ${ }^{1}$

\footnotetext{
Entrevista de Luiz Ruffato concedida à Rádio Unesp no dia 23/02/2018, sobre o lançamento do seu novo trabalho "A cidade dorme", previsto para o primeiro dia do mês de março do ano corrente. Disponível em: $<$ http:// podcast.unesp.br/perfil-23022018-luiz-ruffato-entrevista-2941\%20>.
}

As contribuições de Schøllhammer em sua obra Ficção brasileira contemporânea, publicada em 2009, são fundamentais no processo de contextualização dessas produções que estão ora por se fazerem, ora por serem julgadas, tornando-se um desafio tanto para a crítica e quanto para a historiografia literária, ambas pautadas no cânone. Fenômeno este que acarreta na necessidade de expansão dos métodos de análises para além da teoria literária, em direção aos estudos sociais e culturais.

Nesse artigo, abordar-se-á na obra De mim já nem se lembra, de Luiz Ruffato, a multiplicidade de vozes que ressoam no discurso do narrador e do personagem autor das correspondências, e também sobre as perspectivas assumidas por cada um deles no ato de narrar. Dessa forma, as concepções teóricas de Bakhtin (1999) fundamentam as discussões sobre o romance como representação literária do homem que fala dele próprio e dos outros. Já os subsídios de Cortázar, possibilitam uma leitura sobre o romance como gênero que enfoca problemas de sempre com uma intenção nova e especial que é a de "conhecer e apoderar-se do comportamento psicológico humano, e narrar isso" (2008, p. 65). Como se verá, a obra analisada traz, ainda que de maneira dissimulada, o questionamento, segundo Cortázar, próprio do romance contemporâneo: "seu porquê e seu para quê". Benjamin (2012), Watt (1999) e Rosenfeld (1996) concedem os aportes teóricos necessários para se discutir as peculiaridades do romance - de sua origem à contemporaneidade - e o processo pelo qual as memórias e o gênero epistolar são fagocitados pela narrativa ficcional até a atualidade.

\section{O gênero romance e a configuração da obra De mim já nem se lembra}

Walter Benjamin em seu texto $O$ narrador: considerações sobre a obra de Nikolai Leskov (1936) alega a extinção da arte de narrar em decorrência da privação da faculdade de intercambiar experiências. No entanto, não podemos perder de vista que o narrador a que se refere Benjamin é o narrador da tradição oral. Ao apresentar o surgimento do romance, no início do período moderno, como indício para o fim da narrativa, o teórico observa que o romance, diferentemente de outras formas narrativas, não procede da tradição oral e nem a alimenta. É a relação entre os modos de narrar e as configurações sociais que fundamentam as reflexões e assertivas de Benjamin. Portanto, a narrativa oral está para o sujeito que vive em comunidade e que compartilha experiências, tal como o romance está para o homem moderno que vive segregado e regido pelas ordens do sistema capitalista, individualista e desumano.

Aliado a isto, o pensamento sistematizador de Descartes - quanto à determinação de não aceitar tudo 
passivamente - contribuiu para a concepção moderna da busca da verdade como uma questão inteiramente individual, rompendo a tradição das verdades universais, herdada dos períodos clássico e medieval. Segundo Ian Watt (1990, p.15), o romance constitui a forma literária que reflete mais plenamente uma reorientação individualista e inovadora; seu grande desafio era a fidelidade à experiência individual, o que lhe conferiu um valor sem precedentes em relação à originalidade.

Esse caráter individualista e privado do romance transborda nas narrativas contemporâneas brasileiras, uma vez que é comum a figura de narradores descentralizados, ou seja, que desconstroem padrões eurocêntricos e ideologias de raça, sexo, classe, orientação sexual. Como exemplos, podemos citar Quarto de despejo: Diário de uma Favelada, de Carolina Maria de Jesus, retrata as percepções cotidianas de uma catadora de lixo; Duas iguais, de Cíntia Moscovich, conjuga homoafetividade e judaísmo; O filho eterno, de Cristóvão Tezza, configura a síndrome de Down sob a perspectiva paterna; já em Trapo, do mesmo autor, um professor aposentado torna-se responsável pela avalição e publicação de textos escritos pelo personagem homônimo ao título da obra antes de cometer suicídio; Memórias de um sobrevivente, de Luiz Alberto Mendes, trouxe a perspectiva de um prisioneiro. Inúmeros outros títulos poderiam ser aqui agregados para exemplificar narrativas brasileiras contemporâneas em que a confiabilidade do narrador ganha complexidade em virtude do local de onde emanam suas vozes.

Em De mim já nem se lembra as experiências individuais superabundam pela perspectiva do narrador Luiz e do personagem Célio em suas correspondências. Por se tratar de um romance tecido por intermédio de cartas escritas de um filho para sua mãe, a relação eu-tu dá-se no âmbito da confiança. Dessa forma, a intimidade existente entre emissor e destinatário é fundamental ao tom de afetividade exacerbada que transborda da obra. Luiz, o narrador responsável por lidar com as memórias familiares, de maneira metaficcional, manuseia as cartas de modo a organizá-las em um romance, o que ele chama de reunir o passado, assumindo a postura de autor de uma obra prestes a ser lançada ao crivo de um público desconhecido, em suas próprias palavras: "Aqui reúno esse passado* - modo de reparar meus mortos, que já pesam no lado esquerdo: meu irmão, minha mãe, meu pai, aqueles aos quais me reunirei um dia. A eles, este livro." (RUFFATO, 2016, p. 22).

Paradoxalmente, há entre Luiz e esse material de caráter privado um distanciamento e uma proximidade, pois, ainda que ele não seja nenhum dos locutores das cartas, ele é, como sujeito estético, irmão daquele que as escreve e filho da destinatária, o que inevitavelmente o faz compartilhar dos sentimentos que emanam deste material.
Tal como observado por Rosenfeld (1996, p. 80-81), o romance moderno surgiu com o desfazimento da ordem cronológica por meio de uma fusão entre presente, passado e futuro, experimentada por Proust, Joyce, Gide e Faulkner. De maneira geral, o novo gênero rompe com o mundo onde tempo e espaço mantém-se, pelo realismo tradicional e pelo senso comum, como real e absoluto. Essas categorias, agora relativas e subjetivas, negam o compromisso com o mundo empírico das aparências.

O romance, na concepção de Bakhtin (1998), como gênero híbrido que é, acomoda, além do dialogismo, outras formas que passam a servir a sua diegese, como tentativa de alargar os horizontes, bem como de problematizar uma questão que lhe é cara, a saber: a fronteira entre a escrita e a oralidade. É nessa perspectiva que a obra $D e$ mim já nem se lembra é lida, em outros termos: o gênero correspondência, que poderia sugerir a ideia de estarem a serviço das categorias tempo e espaço como elementos irredutíveis, na composição do romance, instaura o caráter de familiaridade, intimidade, confiabilidade.

Essa relação de subjetividade e relatividade que o narrador estabelece com o material que ele se propõe organizar - as cartas familiares - prende o leitor com tamanha propriedade que possíveis questionamentos sobre a veracidade das histórias narradas, haja vista o nome homônimo do narrador e do autor da obra, a coincidência entre os nomes dos familiares do narrador e os dos familiares do autor tornam-se irrelevantes.

Ao ser questionado sobre a relação estabelecida entre a história de sua família e a obra, haja vista a relação homonímia autor-narrador, em entrevista ao Jornal O Globo, Luiz Ruffato afirmou:

Tudo que está no livro é verdade, mas tudo que está no livro é ficção. [...] as questões nas cartas do irmão são reais, o relato sobre a morte da mãe é próximo do que aconteceu comigo. Mas quem disse que as cartas existem?

O autor conclui seu depoimento com uma reflexão sobre o processo de escrita literária: "Toda literatura, de uma forma ou de outra, é autoficção, mas não gosto daquela que se 'vende' como autoficção"2. Sejam ou não os personagens inspirados em seus familiares, o autor cria um universo literário uno e coeso; sua formalização não se presta a uma simples transcrição, mas sim a uma "imagem de linguagem", em uma concepção bakhtiniana, ou ao que, para Cortázar, equivaleria a "ilusões verbais do romance”. Portanto, as cartas, assim como os depoimentos - Explicação necessária e Apêndice - tratam-se de

\footnotetext{
2 Entrevista de Luiz Ruffato por Guilherme Freitas, concedida à seção Cultura do Jornal on-line $O$ Globo e publicada em 27/03/2016.
} 
recursos estilísticos empregados pelo autor para dar forma ao conteúdo da obra. Tais coincidências corroboram para o caráter de "real" ou "efeito de presença" de que fala Schøllhammer (2009) sobre a literatura brasileira contemporânea.

Muitos romancistas enveredaram pelas cartas como estratégia de configuração de suas obras. Alguns exemplos são: Richardson, em Pamela, Goethe, com o romance $O s$ sofrimentos do Jovem Werther, Dostoiévski, em Gente pobre, Franz Kafka, com Carta ao pai e Graciliano Ramos, com Cartas. O gênero carta reflete, segundo Ian Watt, (1990, p. 154), "a transição da orientação objetiva, social e pública do mundo clássico para a orientação subjetiva, individualista e privada da vida e da literatura dos últimos duzentos anos". Watt assinala ainda que, ao retratar a vida interior de seus personagens, o romance epistolar enfrentar o desafio de reter sua atualidade, uma vez que a "experiência cotidiana do indivíduo compõese de um fluxo incessante de pensamentos, sentimentos e sensações" (WATT, 1990, p. 166). A carta é, nesse contexto, o registro mais próximo da consciência que constitui a personalidade do indivíduo e que determina seus relacionamentos.

É, pois, na perspectiva de Rosenfeld (1996, p. 82) de que "a nossa consciência não passa por uma sucessão de momentos neutros, como o ponteiro de um relógio, mas cada momento contém todos os momentos anteriores" que De mim já nem se lembra é lida. Por meio de seus sujeitos estéticos, o romance revela consciências que englobam presente, passado e futuro.

\section{A engenhosidade do enredo}

Anarrativa inicia-se com o texto intitulado Explicação Necessária, em que o narrador Luiz, pelo recurso de flashbacks, aborda vários planos narrativos do passado familiar. A demarcação de tempo e espaço no romance dá-se de maneira mais subjetiva no discurso de Luiz, normalmente marcados pela personificação dos meses. Expressões como "Fevereiro maltratava o jardinzinho de rosas" (RUFFATO, 2016, p. 11) são recorrentes nas contextualizações feitas pelo narrador. Já nas cartas de Célio, por ser próprio do gênero, informações que se referem ao espaço e tempo apresentam-se de maneira direta e objetiva.

Destarte, a narrativa tem início com Luiz rememorando a visita que fizera à sua mãe, em companhia de sua filha, Helena. O narrador-personagem recorda, então, que, antes de partir, ouvira o prenúncio do que aconteceria com sua mãe, quando Soninha, esposa de Luzimar, interrogou-o: "Luiz, você não achou a madrinha mais magra não?". Foi, então, no fim do mês de março que o diagnóstico veio: câncer.
Envolto no contexto de enfermidade que novamente assolava a família, a narrativa é entrecortada por um fragmento que retoma um tempo anterior ao da referida visita, de modo que o narrador é transportado, por uma espécie de máquina do tempo, para 25 anos atrás, ocasião em que o pai foi acometido por tuberculose. Sob aviso médico de que não teria "mais que uns seis meses apenas", Luiz assistiu à internação do pai no Sanatório Palmira, em Santos Dumont, assim como viu a mãe debruçar-se sobre "quinze trouxas de roupas por semana", a fim de manter o sustendo da família. Esse tipo de suspensão do tempo narrado e regressão a um tempo mais longínquo tornarse-ão recorrentes na narrativa e facilmente identificados pelo leitor por aparecerem no estilo de fonte itálico, destacando-se do tempo presente da narrativa, que permanece em estilo de fonte normal.

O discurso do narrador, ao evocar o passado, vai se tornando cada vez mais rico em imagens literárias construídas por meio de figuras de linguagens. Ao reencontrar-se com a mãe em Cataguases, no mês de agosto, por exemplo, o narrador a descreve: "só ossos sob a camisola de hospital" e observa cuidadosamente que "seus ansiosos olhos castanhos perscrutavam, impotentes, o cortejo do ponteiro dos segundos no relógio despertador".

A metonímia não se restringe à simples substituição da parte pelo todo, mas na representação, nada animadora, do quadro de saúde no qual a mãe se encontrava. Já a personificação do ponteiro do relógio representa não apenas o passar do tempo, mas metaforiza a degradação da vida da mãe, pois anuncia o seu próprio cortejo.

Posteriormente, o narrador confessa: "apavorei-me com o terror que li em seu rosto encovado: a morte a contatara antes". Refugia-se, então, na Praça Rui Barbosa, e escorrega "pela perambeira da infância", rememorando a vida na roça, bem como a convivência com os irmãos, as brincadeiras e as visitas aos parentes. Desse devaneio, como em um estalar de dedos, é bruscamente trazido de volta para o tempo presente por banalidades que ocorrem à sua volta: o homem que conversa com o dono da banca de jornal, a grávida que compra enxoval, o vira-lata com sua coceira, o melancólico vendedor de churros, a velha que o espia pela janela, os aposentados na fila do banco. Estabelecendo relações entre as contradições da vida, o narrador lembra que simultaneamente a tais cotidianidades, "perto dali, num cubículo sombrio e emanando remédio, minha mãe agoniza no claro entardecer".

A morte da mãe lhe fora anunciada às 5 horas da manhã do sábado, dia posterior ao feriado de 07 de setembro de 2001. Passadas as cerimônias da missa de corpo presente e o sepultamento, Luiz asila-se no sítio do amigo Fernando Cesário. Mas, logo the veio a incumbência: "penetrar nos recônditos da casa vazia e separar e ordenar aquilo 
que, embora ainda prenhe dela, já a nada pertencia. [...]. E pus-me à tarefa, antes que, apavorado, recusasse". Ao encontrar, sob a cama de casal, "uma pequena e ignorada caixa retangular de madeira", descobriu que ali estava abrigado "o coração esfrangalhado" de sua mãe. Dentre os objetos que pertenceram a Célio, o filho que fora trabalhar em São Paulo, de onde voltou sete anos mais tarde, em um caixão lacrado, vítima de um acidente automobilístico, encontrava-se "um maço de cartas, cuidadosamente enfeixadas com barbante". A redescoberta dessas cartas é o mote que impulsiona as rememorações do narrador e a sua tarefa em reorganizar esse passado familiar.

É nesse ambiente envolto pelos sentimentos que emanam das recordações que a matéria, segundo Benjamin (2012, p. 221), a "coisa" a ser narrada, mergulha "na vida do narrador":

Em fins de 2003, empacotava objetos para mais uma mudança de endereço - a vigésima sexta em minha vida -, quando, ao retirar livros de uma prateleira na estante, me deparei com o maço de cartas. Imediatamente, sentei-me no chão empoeirado do apartamento vazio e desatei o barbante. Cuidadosamente enfileiradas por data, cinquenta cartas sobrescritadas por meu irmão à minha mãe. Perturbado, percorri, uma a uma, as páginas compostas em letra miúda e desenhada, relatando ninharias, reclamando novidades. (RUFFATO, 2016, p. 22).

Constata-se o processo de inserção do narrador em uma perspectiva memorialística e seu posicionamento diante da matéria narrada, em conformidade com o que assevera Walter Benjamin:

[...] imprime-se na narrativa a marca do narrador, como a mão do oleiro na argila do vaso. É uma inclinação dos narradores começar sua história com uma descrição das circunstâncias em que foram informados dos fatos que vão contar a seguir, isso quando não atribuem essa história simplesmente a uma vivência própria (BENJAMIN, 2012, p. 221).

As cartas conferem, portanto, legitimidade à narrativa de Luiz. Além disso, funcionam como estratégias linguísticas que conduzem à busca pelo "sentido da vida", considerado por Benjamin (2012, p. 230) como o estatuto histórico do romance, e que contrapõe "a moral da história", o estatuto histórico da narrativa.

Outros objetos que Luiz encontrou na caixa que pertencera à falecida mãe se perderam, mas foram por ele conservados os óculos da mãe e uma imagem de sua santa de devoção, "para sempre recordá-la", e as cartas escritas pelo irmão. Essa atitude do narrador revela preocupação no que concerne à necessidade de manter as memórias familiares vivas como estratégia de conhecer a si mesmo, suas origens e, consequentemente, de compreender-se como sujeito histórico e social.

Apesar de fugir da tarefa de reorganizar o passado familiar, o narrador acaba emparedado pelo próprio destino a executar o trabalho que só a ele caberia:

[...] Intocado, o maço de cartas migrou de um móvel a outro, sucumbindo afinal à permanência das cotidianas inutilidades. Receava, embrenhando-me naquele deserto de episódios, afogar-me em traiçoeiras lembranças movediças? Talvez. Mas, mais comezinho, julgo que empurrava-me o orgulho provocado pelo ciúme. Minha mãe cuidou para que a memória do filho mais velho não se desvanecesse e, neste labor, implicava renúncia e provação, distraiu-se de mim, da minha irmã. Pelejei contra essa cisma. Que me acossava as noites, mas o aguilhão picava minha pele (RUFFATO, 2016, p. 21).

Apesar dos ciúmes confesso de Luiz em relação ao tempo que a mãe despendia para com as memórias do filho morto, o narrador assume a responsabilidade, após a morte da mãe, pela manutenção das memórias de Célio. Decorrido um estado de latência, o maço de cartas ressurge diante de Luiz que, sem ter como protelar, enfrentará o labor de organizar o passado que lhe pertence, mas também a muitos outros que se encontram impossibilitados de retomá-lo.

\section{A teia discursiva na configuração do romance}

Ao transpor esse tempo passado em palavras, surge ao narrador a dificuldade não apenas em representá-lo, mas em revivê-lo. Tarefa que só será possível por meio de um narrador que, além de falar, cede espaço para outros, fazendo emanar juntamente ao seu discurso uma multiplicidade de vozes.

Em uma perspectiva bakhtiniana do discurso romanesco, o plurilinguíssimo penetra no texto, materializando-se nas figuras das pessoas que falam ou servindo como fundo direto do romance, e aí está, com efeito, a propriedade do gênero: "o homem no romance é essencialmente o homem que fala" (BAKHTIN, 1998, p. 134). Diferentemente do herói épico, o personagem do romance, além de agir, fala; e sua ação não se acomoda em um mundo significativamente incontestável, tal como no mundo épico. Ao contrário da epopeia, o "romance contém muitas perspectivas, e o herói geralmente age em sua perspectiva particular" (BAKHTIN, 1998, p. 136). A ação do homem no romance é sempre iluminada ideologicamente, associada ao discurso, revelando a posição ideológica do personagem.

No decorrer da obra De mim já nem se lembra outros personagens são trazidos em cena e suas histórias 
justapostas às do narrador. Conforme assevera Bakhtin, a pessoa que fala no romance não é apenas o herói principal, pois é por meio de seu relato que o plurilinguíssimo permeia o romance, trazendo o mundo ideológico de inúmeros personagens. Assim, quando Luiz aceita o desafio e propõe-se a trabalhar com o material das cartas, não oportuniza que apenas a voz do irmão Célio seja ouvida, mas também as de muitos outros, que ecoam de maneira indissociável ao seu discurso. Portanto, muitas outras vozes, além das de Luiz e de Célio, se fazem ouvidas, seja pelo emprego do discurso direto livre, pelo discurso em terceira pessoa ou ainda pelas representações das ações dos personagens. A seguir, algumas passagens da obra exemplificarão tais fenômenos discursivos.

A aproximação da morte, por exemplo, provoca na mãe de Luiz uma nostalgia circunscrita ao ambiente familiar. Sentimento este revelado pelo discurso indireto livre que causa no leitor a sensação de acompanhar, juntamente com Luiz, a morte da mãe.

Sussurrei, Mãe?!, [...] Ah, meu filho, nunca mais vou poder fazer aquela taioba com angu que você tanto gosta... Estou indo embora, meu menino, estou indo embora... E não queria... não queria... Que vai ser do seu pai, coitado, sozinho? E da sua irmã? Ai, meu deus, meu deus... (RUFFATO, 2016, p. 15).

Outro exemplo do discurso indireto livre diz respeito à perspectiva ideológica do caseiro Gésus, evidenciada quando da visita de Luiz, após a morte da mãe. Em um primeiro momento, há um pronunciamento truncado, em que as palavras surgem, em meio ao embaraço, apenas para manter o canal de comunicação com seu interlocutor:

[...] cigarro pendurado dos lábios, surgiu, repreendendo os vira-latas, Bicho besta, sô! Embaraçado, apertou minha mão, meus pêsames, seu Luiz, o doutor Fenando avisou. O senhor aceita um cafezinho? [...] (RUFFATO, 2016, p. 18).

Estabelecida a comunicação, “[...] Gésus condoeu-se, talvez, e deliberou a falar [...]". O personagem, revelando sua perspectiva de mundo, fala sobre coisas do seu cotidiano: a criação de peixes, a praga do muçum, as minhocas, o orquidário.

Os discursos de muitos personagens aparecem, nas cartas de Célio, sob a forma de conselhos. Já na primeira carta, datada de " 2 de fevereiro de 1971", em que Célio relata a viagem de Cataguases a São Paulo e o seu aposento na cidade grande, o conselho do pai é lembrado: "Fala com ele que eu não esqueci dos conselhos dele não: só falo com as pessoas que o Nilson me diz que é colega dele ou conhecido". Em cartas posteriores, os conselhos continuam em efervescência. Há aqueles que foram transmitidos pelos pais: "[...] mas sei que, como fala o pai, a gente tem que tentar melhorar de vida e não pode escolher os caminhos" e "Mas, o trabalho, como a senhora mesmo disse, ajuda a gente nessa hora". E também os que recebera de pessoas conhecidas: "A dona Brenda falou que é para preparar porque está esfriando e quando esfria aqui é um negócio. [...] todo mundo me falou que isso não é nada ainda"; "O pessoal mais antigo fala que daqui a pouco vou ficar com nojo da comida".

Célio além de receber sabe também dá conselhos, tal como se observa nessa passagem em que se refere ao irmão Luizinho: "[...] ele tem que ter incentivo. A senhora deve falar com ele sobre isso, para ele se esforçar nos estudos, que é a única maneira da gente subir na vida".

Célio representa a figura do viajante, aquele narrador de Benjamin que tem histórias para contar, apesar de fazêlo por escrito e não oralmente. Eis aí a questão: mesmo transmitindo experiências próprias e também de outros, dando e recebendo conselhos, ao fazê-lo pela escrita, institui a marca do narrador moderno. Esse aspecto da obra não se refere a uma tentativa de incluir no romance algum ensinamento, o que, para Benjamin, resultaria na "transformação da própria forma romanesca". Trata-se, pois, de uma estratégia narrativa, uma vez que ao propor esse narrador viajante que traz a experiência por meio da escrita, Ruffato reelabora e ressignifica a tradição a que o romance se vincula, a escrita. Como homem moderno, Célio seria aquele "que não pode falar exemplarmente sobre suas preocupações mais importantes e que não recebe conselhos nem sabe dá-los" (BENJAMIN, 2012, p. 217-218). Portanto, ele escreve e, como sujeito moderno, seus conselhos não são aqueles exemplares para uma comunidade, mas sim os privados e de âmbito familiar. Seu discurso nasce em um local de exílio e trata de coisas íntimas. Luiz, outro sujeito moderno que usa a técnica da escrita, também reelabora o passado sob a mesma perspectiva do irmão. Cada qual em seu tempo e de sua maneira, ambos revelam as inquietações pessoais, falando por si e também por outros sujeitos estéticos que não puderam narrar suas próprias histórias.

As falas dos personagens presentes nas cartas de Célio - dele próprio, da mãe, do pai, do amigo, do chefe, do encarregado, das donas das pensões - vão se entrelaçando e dando corpo à composição do romance. Dessa maneira, "uma parte considerável de palavras significativas de outrem" (BAKHTIN, 1998, p. 153) integram o discurso de Célio proporcionando uma interação dialógica mútua.

Conforme a proposição bakhtiniana de que as ações dos personagens, narradas em terceira pessoa, expressam sua posição ideológica. Diz ele: 
O romancista pode também não dar ao seu herói um discurso direto, pode limitar-se apenas a descrever suas ações, mas nesta representação do autor, se ela for fundamental e adequada, inevitavelmente ressoará junto com o discurso do autor também o discurso de outrem, o discurso do próprio personagem (BAKHTIN, 1998, p. 137).

Portanto, a formalização sintática do discurso alheio não se esgota nos modelos gramaticais do discurso direto e indireto, estendendo-se nas ações dos personagens perspectivadas pelo narrador. É o que acontece, por exemplo, com a figura do pai, o vendedor ambulante de doces construída, tanto pelo narrador quanto por Célio, em torno de seu comportamento pacato; dona Glenda, a proprietária da pensão em que morara Célio, devido ao seu comportamento bondoso, é por ele retratada como "uma mãe de todos".

Célio também emite inúmeros julgamentos sobre a irmã. O personagem pauta-se nos relatos da mãe nas prováveis cartas-respostas ou nas suas próprias análises, quando das visitas à família em Cataguases. Além do ponto de vista de Célio, o seu discurso faz ressoar um julgamento coletivo sobre o comportamento de Lúcia: "[...] continua a mesma: a senhora viu como ela ficou brava só porque falei do tamanho da minissaia dela? Aquilo é uma indecência [...]"; "Quer dizer que Lúcia já terminou o namoro com o Agnaldo? É, ela não tem jeito não [...]"; "Ô menina opiniúda, mãe. Só pensa em namorar, em roupa, em rádio". Célio tranquiliza-se em relação à irmã quando do anúncio de seu casamento, considerado por ele como "a notícia boa". Por outro lado, a conduta do irmão Luiz o tranquiliza, como se constata em passagens como: "O Luizinho, $[. .$.$] acho que ele está$ bem encaminhado, graças a Deus"; "Gostei de ver o Luizinho. Está estudando bastante"; “[...] está crescido e ajuizado"; ou ainda, "[...] tem cabeça no lugar e vai se dar bem na profissão".

Ainda que sem adentrarmos numa discussão sobre o engajamento político-social ao qual se vincula o romance De mim já nem se lembra, cabe uma ressalva, qual seja: que as correspondências, ainda que ironicamente tratadas por Luiz como "ninharias" e "reclames de novidades", o romance filia-se a uma identidade coletiva e carrega consigo uma memória histórica e política brasileira da década de 70 do século XX. Os posicionamentos ideológicos dos personagens fazem-se ouvir por um engajamento que extrapola os limites das cartas familiares. Segundo Bakhtin, o sujeito que fala no romance é um "homem essencialmente social" e "seu discurso é uma linguagem social", suas palavras não estão servindo ao acaso, mas "pretendem uma certa significação e uma certa difusão social" (BAKHTIN, 1998, p. 135). Nessa perspectiva, o romance funciona como uma espécie de máquina do tempo, conduzindo o próprio narrador a refletir sobre um passado que lhe é simultânea e paradoxalmente - comum e alheio, pois as narrativas constituem memórias não apenas familiares, mas também coletivas, das quais emana uma gama de conteúdos históricos, sociais e políticos.

Assuntos como migração e imigração, industrialização, movimentos sindicais, Ditadura Militar, são abordados pelo narrador das cartas, em que se constatam também episódios históricos pontuais, tal como jogos de futebol nos estádios do Morumbi e do Maracanã, dentre eles, a Copa do Mundo de 1974.

A morte precoce de Célio encerra a sua história às vésperas de grandes movimentos sindicais e grevistas no $\mathrm{ABC}$ paulista, os quais abalariam o Regime Militar e, por conseguinte, abririam caminho para a fundação do Partido dos Trabalhadores - PT. Devido à morte trágica de Célio, as cartas findam-se e o fio narrativo das correspondências é suspenso. Daí o importante papel do personagem-narrador Luiz que, após tentativas de se esvanecer, entrega-se à tarefa de reorganizar esse passado.

\section{Considerações finais}

De mim já nem se lembra é uma obra memorialística construída em torno do gênero epistolar, do qual o autor, Luiz Ruffato, utiliza-se para construir o discurso confessional, íntimo e familiar a que se propõe. Inevitável e propositalmente, as cartas trazem à narrativa uma experiência cotidiana e privada, o que é próprio do gênero. São as correspondências que possibilitam que fragmentos do passado de Célio e de outros sujeitos estéticos fossem reconstruídos por Luiz. Mas, ao organizar e narrar essas histórias, Luiz engendra-se em um processo de entendimento do seu próprio eu. $\mathrm{Na}$ parte final do romance, o mundo é dito por ele, de modo que os acontecimentos narrados pelo irmão em suas cartas são filtrados e apresentados por sua percepção de verdade e perspectiva memorialística.

Ao longo da obra, fragmentos atuais misturamse, de forma pungente, com experiências remotas e com expectativas futuras. As cartas funcionam como possibilidade de aparecimento do fluxo psíquico de Célio, provocando o desaparecimento do "intermediário", o narrador em terceira pessoa, assim como da causalidade, base do enredo tradicional, de acordo com Rosenfeld (1996, p. 84). Ao negar o compromisso com o mundo temporal e espacial posto como "real e absoluto", a arte moderna relativiza as categorias de espaço e tempo e, portanto, incorpora ao romance, o que o teórico chama de "fundamentalmente novo".

Ainda que as marcas temporais e espaciais sejam partes fundamentais do gênero correspondência, a estru- 
turação do romance faz com que problemas morais, políticos e sociais transcendam essas categorias, constituindo uma unidade mítica. Célio é, pois, uma configuração arquetípica do ser humano, representando o mito do eterno retorno. Após sair de seu local em busca de uma vida melhor - tal como Ulisses, que se aventurou na guerra de Tróia -, quer voltar para casa. No entanto, diferentemente do personagem grego, o regresso, para Célio, não é mais possível. Abalado e absorvido por um mundo caótico, com problemas advindos da modernidade, seu retorno não será guiado pelos deuses; culminará em sua morte a caminho de Cataguases.

Luiz e Célio se constroem ao fim da narrativa: o primeiro tem a possibilidade de retomada do discurso para si, em Apêndice, quando narra o telefonema que recebera da irmã Lúcia, na ocasião dos 30 anos da morte de Célio. Após ouvir seu choro, senta-se no sofá e, resistindo à vontade de voltar a fumar, rememora a convivência com o irmão. Nesse ponto da narrativa, o fluxo de consciência culmina na radicalização extrema do monólogo interior e "a consciência do personagem passa a manifestar-se na sua atualidade imediata" (ROSENFELD, 1996, p. 84). Luiz assume as rédeas da narrativa ao ponto de forjando um diálogo com o irmão: "Lamento termos convivido tão pouco. Eu tinha 10 anos quando você tomou o rumo de Diadema [...]" (RUFFATO, 2016, p. 133); já Célio se constrói não exclusivamente pelo próprio discurso, pois o acidente automobilístico ceifa sua vida e interrompe as trocas de correspondências com a mãe, mas também pela reconstituição de seu passado realizada pelo irmão.

Neste ponto está a engenhosidade do autor, qual seja: fazer uso de um gênero que carrega marcas temporais e espaciais como elementos próprios de sua composição para construir o romance quanto ao seu tema e forma. Luiz Ruffato elabora, por meio dos jogos discursivos memorialísticos de seus narradores, um universo fictício que transcende tempo e espaço, de modo a fazer experiências individuais expandirem-se para outros sujeitos, a saber, os leitores, pois estes compartilham da mesma condição humana de seus personagens.

O leitor permeia todo o texto acompanhado da constante interrogação sobre o "porquê?" e o "para quê?" do romance contemporâneo, como sugere Cortázar (2008), assim como o narrador Luiz que, mesmo sem resposta, é impulsionado a narrar. As cartas são datadas, mas as experiências vivenciadas pelos personagens não são marcadas temporalmente, tratam-se de rememorações.
Ou seja, não são narradas como experiências cerradas em um tempo passado. Tampouco como experiências exclusivamente particulares, pois o plurilinguíssimo do romance forma um coro de múltiplas vozes que ecoa não apenas no íntimo do narrador, mas também no leitor, irrompendo do passado para a atualidade.

\section{Referências}

BAKHTIN, M. A pessoa que fala no romance. In: Questões de literatura e de estética: a teoria do romance. Tradução Aurora Fornoni Bernardini et al. 4. ed. São Paulo: Unesp, 1998.

BENJAMIN, W. A crise do romance: sobre Berlin Alexanderplatz, de Döblin. In: Magia e técnica, arte e política: ensaios sobre literatura e história da cultura. Tradução Sérgio Paulo Rouanet. 8. ed. São Paulo: Brasiliense, 2012. p. 55-61.

BENJAMIN, W. O narrador: considerações sobre a obra de Nikolai Leskov. In: Magia e técnica, arte e política: ensaios sobre literatura e história da cultura. Tradução Sérgio Paulo Rouanet. 8. ed. São Paulo: Brasiliense, 2012. p. 213-240.

CORTÁZAR, J. Situação do romance. In: Valise de cronópio. Tradução D. Arriguci Jr. e J. A. Barbosa. São Paulo: Perspectiva, 2008. p. 61-83.

ROSENFELD, A. Reflexões sobre o romance moderno. In: Texto/Contexto I. 5. ed. São Paulo: Perspectiva, 1996. p. 75-97.

RUFFATO, Luiz. De mim já nem se lembra. São Paulo: Companhia das Letras, 2016.

RUFFATO, Luiz. Entrevista [27 de Mar. 2016]. Entrevistador: FREITAS, Guilherme. Rio de Janeiro: Jornal on-line $O$ Globo, 2016. Entrevista concedida à seção Cultura do Jornal on-line O Globo. Disponível em: <http://oglobo.globo.com/cultura/ livros/cada-romance-uma-tentativa-de-reconstruir-historia-dizruffato-18960961\#ixzz4Wy09Iw4R>. Acesso em: 26 jan. 2017.

RUFFATO, Luiz. Entrevista [23 de Fev. 2018]. Bauru: Rádio Unesp, 2018. Entrevista concedida à seção Últimos Pods da Rádio Unesp. Disponível em: <http://podcast.unesp.br/perfil23022018-luiz-ruffato-entrevista-2941\%20>. Acesso em: 26 mar. 2018

SCHØLLHAMMER, Karl Erik. Ficção brasileira contemporânea. Rio de Janeiro: Civilização Brasileira, 2009.

WATT, Ian. A ascensão do romance. Tradução Hildegard Feist. São Paulo: Companhia das Letras, 1990.

Recebido: 04/07/2018

Aprovado: 25/09/2018

(D) DANIELE CRISTINA DA SiLVA <daniele.silva@tga.ifmt.edu.br> Professora do Instituto Federal de Educação, Ciência e Tecnologia do Mato Grosso (IFMT).

(D) WALNice Aparecida Matos Vilalva

Professor do Programa de Pós-Graduação em Estudos Literários (PPGEL) da Universidade do Estado de Mato Grosso. 